
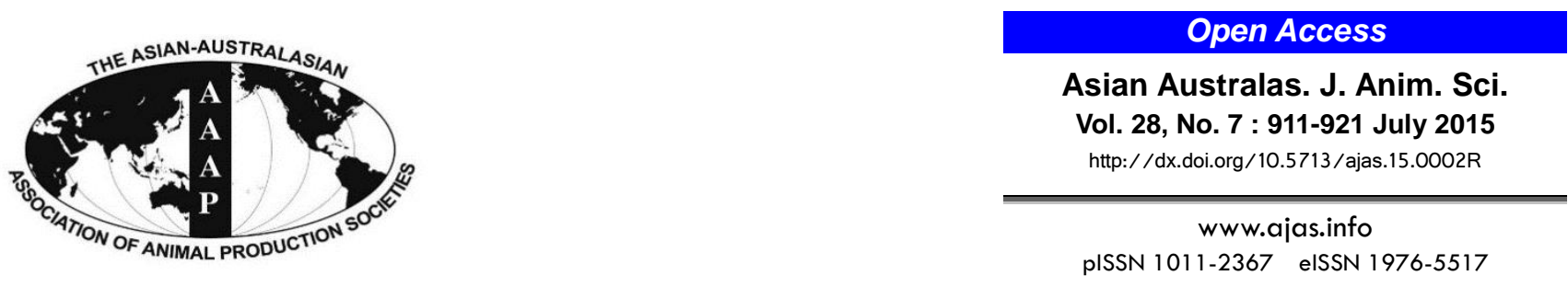

\title{
- Invited Review - \\ African Indigenous Cattle: Unique Genetic Resources in a Rapidly Changing World
}

\author{
Okeyo Mwai, Olivier Hanotte ${ }^{1}$, Young-Jun Kwon ${ }^{2}$, and Seoae Cho ${ }^{3 * *}$ \\ International Livestock Research Institute, Nairobi PO Box 30709, Kenya
}

\begin{abstract}
At least 150 indigenous African cattle breeds have been named, but the majority of African cattle populations remain largely uncharacterized. As cattle breeds and populations in Africa adapted to various local environmental conditions, they acquired unique features. We know now that the history of African cattle was particularly complex and while several of its episodes remain debated, there is no doubt that African cattle population evolved dramatically over time. Today, we find a mosaic of genetically diverse population from the purest Bos taurus to the nearly pure Bos indicus. African cattle are now found all across the continent, with the exception of the Sahara and the river Congo basin. They are found on the rift valley highlands as well as below sea level in the Afar depression. These unique livestock genetic resources are in danger to disappear rapidly following uncontrolled crossbreeding and breed replacements with exotic breeds. Breeding improvement programs of African indigenous livestock remain too few while paradoxically the demand of livestock products is continually increasing. Many African indigenous breeds are endangered now, and their unique adaptive traits may be lost forever. This paper reviews the unique known characteristics of indigenous African cattle populations while describing the opportunities, the necessity and urgency to understand and utilize these resources to respond to the needs of the people of the continent and to the benefit of African farmers. (Key Words: Africa, Cattle, Climate, Indigenous Genetic Resource)
\end{abstract}

\section{INTRODUCTION}

Once humans started domesticating animals, livestock populations have continually been influenced through selective breeding in response to the needs of the owners as well as through natural selection to adapt to the local agroenvironment. Animal breeding was initially practiced to obtain usable products or services and for socio-cultural (e.g. religions, aesthetic) reasons (Flint and Woolliams, 2008). Although ancient breeding schemes might have existed, knowledge-based selective breeding was first practiced by the Romans (Buffum, 1909). Now, with recent

\footnotetext{
* Corresponding Author: Seoae Cho. Tel: +82-2-876-8820, Fax: +82-2-876-8827, E-mail: seoae@cnkgenomics.com

${ }^{1}$ School of Life Sciences, University of Nottingham, Nottingham, NG7 2RD, UK.

${ }^{2}$ Interdisciplinary Program in Bioinformatics, Seoul National University, Seoul 151-742, Korea.

${ }^{3}$ CHO\&KIM genomics, Seoul 151-919, Korea.
}

technological developments, both phenotypes measurements and genomic information are now being used for genetic improvements (Flint and Woolliams, 2008). In particular, methods for obtaining genomic information of animals are developing rapidly (e.g. genome-wide genotyping and sequencing), thus opening new opportunities for genomic selection (Habier et al., 2007; Hayes et al., 2013).

However, the commercial livestock sector is facing several new challenges. Demand for livestock products is continuously increasing, but long-term sustainability of the intensive livestock sector is questionable (Otten and Van den Weghe, 2011). Climate change is putting new pressures on livestock production, while livestock themselves are contributing through greenhouse emissions to the climate change (Houghton et al., 1992; Nardone et al., 2010). Moreover, indigenous livestock, although adapted to the local environments, are poor milk and meat producers compared to the commercial breeds raised in the extensive system (Renaudeau et al., 2012). 
Arising from the above concerns and the need to bridge the huge productivity gaps in developing countries, catalyzed by rapid changes in the production systems, more than ever indigenous livestock genetic resources, which constitute the largest proportion of livestock in those countries, are increasingly being eroded through poorly planned crossbreeding and breed replacements. In process, we might be losing unique genetic attributes, especially those responsible for adaptations to the past, current, and even future African environmental challenges, such as parasitic infectious diseases, heat and drought tolerance etc. Here, we summarize the adaptation of indigenous African cattle emphasizing the importance and need to unravel and characterize these cattle at genome level.

\section{THE ORIGIN OF AFRICAN CATTLE}

Currently, about 180 breeds of cattle have been recognized in sub-Saharan Africa; 150 breeds of indigenous cattle and recently introduced exotic and commercial composites (Rege, 1999; Rege et al., 2006). However, often the genetic distinctiveness between these cattle breeds remain largely unknown and it may be more appropriate to talk about African cattle populations or ecotypes. Phenotypically humped cattle or zebu cattle (Bos indicus) constitute the majority of African cattle (Hanotte et al., 2000). They are adapted to local environmental conditions that are generally unsuitable to exotic breeds of European origin (e.g. high temperatures, long period of drought, vector-born disease). African indigenous taurine cattle Bos taurus (humpless cattle) are now found nearly exclusively in West Africa, while commercial taurine breeds and their crossbreed are found almost in every part of the continent, although their populations are relatively low compared to the indigenous breeds. Beside these two main types of cattle, the continent is home to sanga and zenga, which are crossbreds between the indigenous taurine and zebu (sanga), and zebu and sanga (zenga), with the latter having higher zebu genetic background than the former (Rege, 1999). It should be noted, that all African cattle do carry a taurine mitochondrial DNA, in others words they are no pure zebu Bos indicus on the African continent.

The wild auroch, Bos primigenius, is the progenitor of all taurine and zebu cattle (Edwards et al., 2007). They are described by Julius Caesar in his report of the Gallic Wars as "...a little below the elephant in size, and of the appearance, color, and shape of a bull". Three subspecies of auroch are recognized. According to fossil record, Northern Africa was the habitat of $B$. p . africanus from Middle Pleistocene onwards (Linseele, 2004), B. p. primigenius was widely distributed in western Eurasia, while the supposedly wild ancestor of zebu B. p. nomadicus inhabited South Asia (Stock and Gifford-Gonzalez, 2013).
Estimates of divergent time for Bos taurus and Bos indicus from a common ancestor are all pre-Neolithic ranging from to $\sim 2$ millions to $\sim 330,000$ years ago depending of the genetic markers and the calibration rate of the molecular clock (Hiendleder et al., 2008; Ajmone-Marsan et al., 2010). It remains unclear whether or not African cattle were domesticated on the African continent. It was originally thought that it might have been the case following molecular evidence indicating the presence of a "unique" African mitochondrial DNA $D$-loop haplogroup (Loftus et al., 1994) and archaeological remains of ancient cattle husbandry in the East of the Sahara desert (Wendorf and Schild, 1994). However, the close sequence similarity between cattle D-loop mtDNA haplogroups (Troy et al., 2001) and more recently, a study using the full cattle mitochondrial DNA sequences (Bonfiglio et al., 2012), showing that the diversity of African mitochondrial DNA is largely embedded within the mitochondrial DNA diversity of Near East cattle, support that the maternal ancestor of African domestic cattle may have originate from the same center of cattle domestication and/or auroch populations than the European taurine, in the Fertile Crescent. However, a genome-wide study using single nucleotide polymorphic makers indicates the presence in African cattle of a unique genetic background which was postulated to have originated from the African auroch through a male mediated introgression process (Decker et al., 2014).

Archaeological and molecular data allow making inferences about the history of African cattle, including their possible migration routes within the African continent (Figure 1; Hanotte et al., 2002; ILRI, 2006; Stock and Gifford-Gonzalez, 2013). Humpless Bos taurus are considered the earliest African cattle as supported by archaeological evidence and pictorial accounts (e.g. Sahara rock paintings) (Blench and MacDonald, 2000). The humpless longhorns might have been introduced first, followed by humpless shorthorns cattle about 2,500 years later (Epstein, 1971; Rege, 1999). However, it should however be pointed out that the two waves scenario of taurine arrival into Africa is yet to be supported by any molecular evidence. Hanotte et al. (2002) showed that African Bos taurus cattle expanded from the northeastern part of the continent to the West and East Africa (Hanotte et al., 2002). After the initial taurine cattle dispersion, zebu cattle were introduced into the continent, likely in two waves (Hanotte et al., 2002). It is possible that the first African cattle reaching the Southern part of the continent were zebu-introgressed taurine cattle (Epstein and Mason, 1971; Hanotte et al., 2002), Although zebu cattle were probably present in Africa earlier than 2000 BC, the first wave of zebu introduction through the Horn of the continent, is thought to be primarily associated with the development of the Swahili-Arabs civilization along the East African 


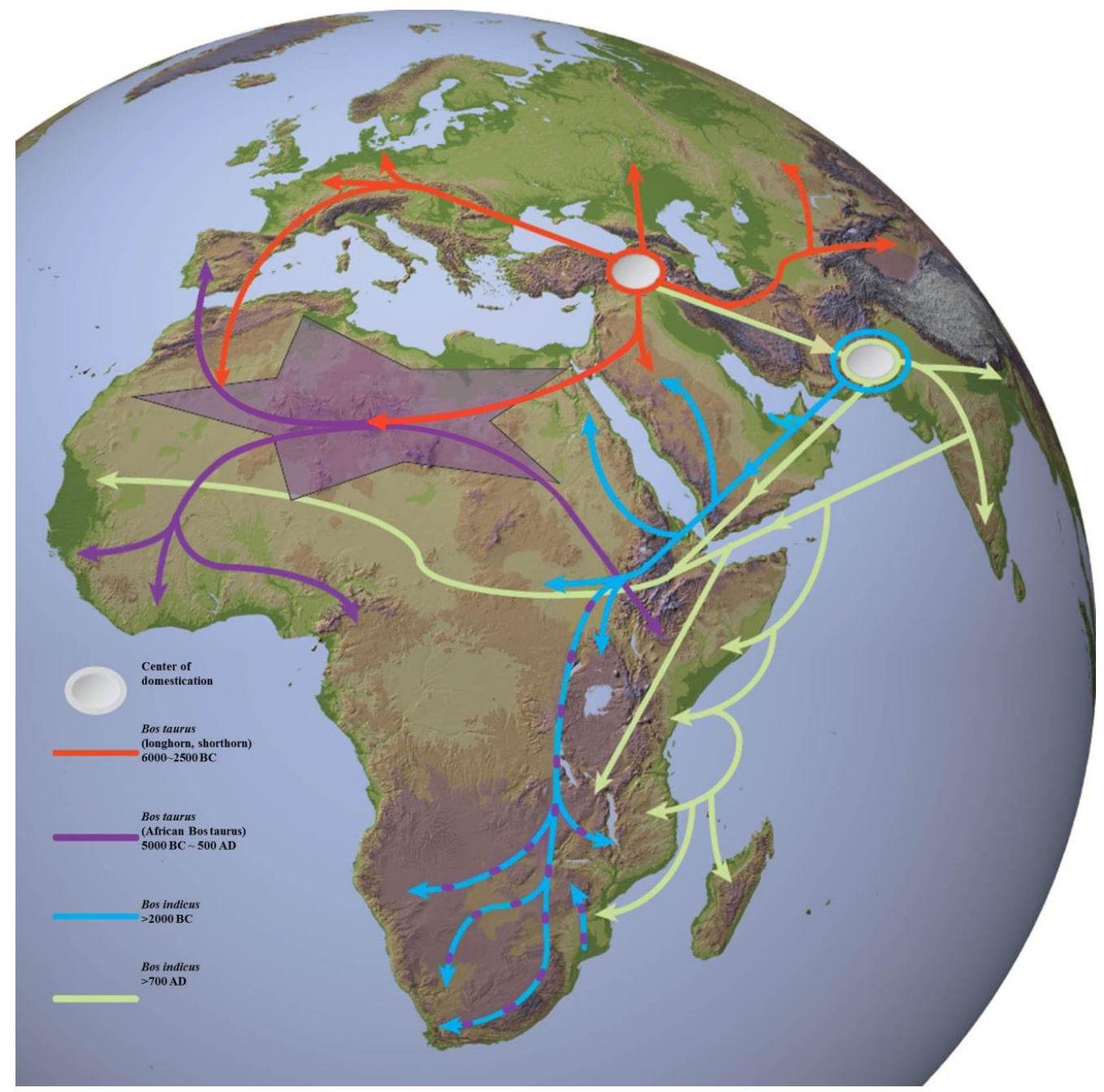

Figure 1. Approximate migration route and the origin of Africa domestic cattle (adapted and modified from ILRI, 2006. Safeguarding livestock diversity: the time is now). Circle regions represent the expected center of cattle domestication. Migration route from the outside Africa and within Africa was shown by color arrows, and the color of arrow represents the migration time and its origin.

coast from the 7th century AD. The second wave of Bos indicus, perhaps followed the rinderpest epidemics of 19th century, which wiped out most of African cattle population.

\section{TYPES OF INDIGENOUS CATTLE AND THEIR GEOGRAPHIC DISTRIBUTION}

\section{Main groups of African cattle}

Indigenous African cattle can be broadly classified into four categories: humpless Bos taurus, humped Bos indicus, sanga (African humpless Bos taurus $\times$ humped Bos indicus hybrid), and zenga, defined as sangaxzebu backcross. In addition to these four categories, other African cattle breeds have been recently derived through recent crossbreeding with exotic (Rege and Tawah, 1999).

African Bos taurus includes two groups, humpless shorthorns and longhorns. They mostly inhabit West and Central Africa. Both these groups are small in size and their productivity is lower compared to most of the zebu cattle populations in tropical areas (Rege, 1999). However, they have unique evolutionary adaptation to harsh climate (Hansen, 2004) and various endemic diseases (Murray et al., 1984; Mattioli et al., 2000). One of these adaptations is their documented tolerance to trypanosomosis (Roberts and Gray, 1973), a parasitic disease due to infection with Trypanosoma sp. whose vector is the tsetse fly.

Zebu cattle (Bos indicus), are the majority of cattle types in Africa. They have a fatty thoracic hump on their shoulders and a large dewlap. The zebu is usually susceptible to trypanosomosis (Murray et al., 1982) however, tolerance to the disease has been documented in the Orma Boran, an East African zebu breed (Njogu et al., 1985). They are adapted to dry environmental conditions and high temperatures and are known to be more resistant to tick infestation compared to Bos taurus cattle (Mattioli et al., 2000). African zebu cattle inhabit western and eastern parts of Africa. Their large body size and high production levels in tsetse-free areas have made them more appealing 
to the local farmers, and therefore partly explain their abundance and wide distributions in Africa.

The sanga is an intermediate type of cattle, which is a cross between Bos taurus and Bos indicus. They are humped but the hump is cervico-thoracic rather than thoracic. They inhabit eastern and southern Africa and are known to be well adapted to seasonally harsh conditions (Okello and Sabiiti, 2006). It is thought that sanga cattle were derived by hybridization between taurine cattle and zebu around 700 AD (Hanotte et al., 2002). Crossbreeding between sanga cattle, and newly introduced zebu led to a new cattle type called "Zenga" (Rege, 1999). Zenga are found in eastern Africa.

Although, African cattle genetic diversity remains large, cattle populations or breeds continue to face extinction. According to Rege (1999), 22\% of African cattle breeds have already become extinct in the last century and $32 \%$ of indigenous African cattle breeds are in danger of extinction (Rege, 1999). Moreover, some breeds that are critically endangered have fewer than 1,000 animals, such as the Ghana Dwarf Muturu (humpless shorthorns), Mkalama Dun (Small East African Zebu), Pare (Small East African Zebu), Chagga (Small East African Zebu), Baria (Small East African Zebu), Nkone (South African sanga), Pedi (South African sanga), and Shangan (South African sanga) (Rege, 1999). To compensate for the relatively lower production potential of indigenous cattle, crossbreeding of these cattle with exotic breeds, is commonly practiced, with minimal within breed selection program for the indigenous breeds. The end result is a continuous erosion and loss of cattle diversity, including for adaptive traits, before these genetic resources are fully characterized. There is therefore an urgent need to comprehensively characterize the African cattle populations, in order to objectively inform their utilization and conservation before they disappear (Hanotte et al., 2010).

\section{Main subgroups of African cattle}

The humpless Bos taurus includes two groups, humpless longhorns and humpless shorthorns. They are currently found in West and Central Africa (Rege et al., 2006). Sanga cattle are mainly kept in eastern and southern Africa, but they are also found in Central Africa. The distribution of the five African cattle groups including the recent derived breeds is shown at Figure 2 (Rege, 1999; Hanotte et al., 2002; Rege et al., 2006).

Overall, cattle population density is highest in the East African highlands compared to other regions, a legacy of the history of cattle introduction and human migration on the African continent (Figure 1). The two waves of Bos indicus migration led to a dominance of zebu type cattle among the East African indigenous cattle, thus replacing

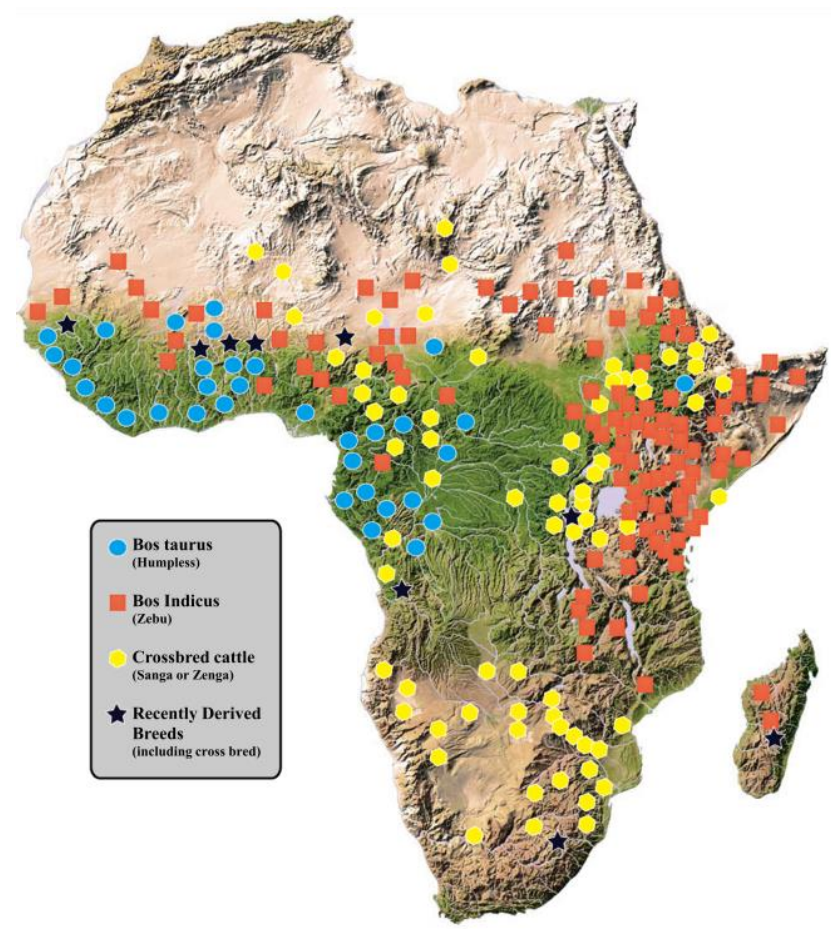

Figure 2. Distributions of indigenous cattle in sub-Saharan Africa. Marks on the map represent African cattle distribution, and each mark shows the type of cattle which inhabit the region. Cattle of North Africa and imported commercial cattle breeds are not shown in this figure.

nearly, if not all, East African Bos taurus cattle (Payne, 1964; Epstein and Mason, 1971; Hanotte et al., 2002). Together, $Y$ chromosome, autosomal and mtDNA studies clarify the introgression pattern of zebu cattle (Bradley et al., 1994; Hanotte et al., 1997, 2002; Porto-Neto et al., 2013). All genetic evidence suggests that zebu introgression on the Africa continent was primarily a male zebu process. While this might be expected for a polygenous species like cattle, it is nevertheless surprising that not a single zebu mitochondrial DNA have been so far been identified on the African continent. The reason(s) are unclear. Perhaps, zebu mitochondrial DNA haplotypes might have been selected against in crossbreed cattle living on the African continent. Further studies are therefore needed.

Admixture analyses of African cattle using microsatellite data have revealed a gradient of Bos indicus introgression across the African continent (Hanotte et al., 2002), with the level of zebu introgression decreasing from eastern to western Africa (Hanotte et al., 2002; Freeman et al., 2006). Moreover, cattle that inhabit subtropical areas of West and Central Africa barely have any zebu ancestry. Given the susceptibility of most zebu cattle populations to trypanosomosis, tsetse-infested areas in subtropical areas most likely prevented introgression of zebu ancestry into these populations (MacHugh et al., 1997). 


\section{CHARACTERISTICS OF AFRICAN INDIGENOUS CATTLE}

African indigenous cattle breeds have unique morphological features which distinguishes them from other cattle. These include horn shape and size (e.g. Ankole and Kuri) (Rege et al., 2006; Ndumu et al., 2008; Kugonza et al., 2011; Terefe et al., 2015). In addition to physical features, non-visible traits such as disease resistance, climatic stress resistance and productivity traits also differ among breeds. These characteristics are largely the result of natural and human selection. Some breeds are already known for their unique adaptive attributes (e.g. Muturu) or good economic performances (e.g. Kenya Boran).

One of the well-known outstanding features of African cattle is trypanosomosis resistance. Trypanosomosis is a tsetse-transmitted disease in vertebrates. In cattle the main pathogenic trypanosomes are Trypanosoma congolense and T. vivax. Non-African cattle breeds are highly susceptible to trypanosomes infection. The African Bos taurus are tolerant while African Bos indicus are susceptible although not as susceptible as the non-African Bos taurus and Bos indicus exotic breeds. For instance, the N'Dama cattle (a long humpless longhorns), which are found in central and West Africa, are trypanotolerant (Mattioli et al., 2000), which has led to an overall population increase and expansion of their geographical range (Rege and Tawah, 1999). Other studies have reported that the Sheko cattle (an East African humpless shorthorns) shows also resistance to trypanosomosis (Lemecha et al., 2006). Unfortunately today, this cattle breed is rapidly disappearing as result of being increasingly being crossed with trypanosusceptible zebu cattle. Although zebu cattle are usually susceptible to trypanosomosis, some zebu breeds that inhabit tsetseinfested regions, such as the Nuba Mountain Zebu, Mongolla or the Orma Boran, and the Mursi have been reported to have relatively reasonable levels of tolerance to trypanosomosis, as a result of local evolutionary adaptation (Ruttledge, 1928; Rege and Tawah, 1999; Terefe et al., 2015). Also, the Bovino de Tete, which is a zenga type of cattle found in Mozambique and the Alur cattle found in the Democratic Republic of Congo, are also thought to show some level of trypanotolerance (Lemecha et al., 2006).

Tick infestation represents another major challenge for African cattle. Unlike trypanosomosis, African Bos indicus cattle are believed to be more resistant to infestation by cattle ticks compared to taurine animals (Piper et al., 2009). However, among African taurine cattle, the N'Dama and Ankole (humpless longhorns) have been reported to be resistant to tick infestation (Mattioli et al., 2000). In addition, Tswana cattle (South African sanga), from Botswana, have very high tolerance to heavy tick challenges (Rege et al., 2006). The Tswana is also known to have resistance to the endemic heartwater disease, as do Landim cattle (South African sanga) from Mozambique (Asselbergs et al., 1993).

Distinct evolutionary history between Bos taurus and $B$. indicus have resulted in different degree of thermostolerance at the cellular and physiological levels (Hansen, 2004). Bos indicus breeds can effectively regulate their body temperature against thermal stress and are better adapted to hot weather than Bos taurus breeds (Hansen, 2004). In addition, several breeds of zebu and zenga are able to withstand very harsh environmental conditions, and those characteristics have arisen through evolutionary adaptation. For examples, Karamajong Zebu cattle (Large East African Zebu) in Uganda are well adapted to very dry climates and they can survive if they are able to drink only once every two days (Thomas, 1943). Turkana cattle (Large East African Zebu) in Kenya, which are classified in the same subgroup of cattle, are thought to be able to survive on very poor pasture, scarce water and have good walking abilities (Rege et al., 2006). Angoni cattle (Small East African Zebu) in Zambia and Ugogo Grey cattle (Small East African Zebu) in Tanzania are adapted to browsing during the long dry seasons (Felius, 1995; Rege and Tawah, 1999). In the case of Landim cattle (South African Sanga) in Mozambique, they are thought to have resistance to hot, humid weather as well as extended dry periods and foot and mouth disease (Felius, 1995; Rege et al., 2006; Machiel, et al, 2013). In Africa, cattle breeds have adapted to hot and dry weather, but others have adapted to even cold and wet conditions, such as Jem-Jem cattle (Small East African Zebu) in Ethiopia (Rege and Tawah, 1999).

African cattle continue to play a major role in the socioeconomic development and nutritional security of the people of the continent (Table 1). It is likely that some the earliest African societies depended only on livestock given their nomadic lifestyle (Marshall and Hildebrand, 2002). Pastoralism remains an important activity in the continent today, and exemplified by the Fulani, Maasai and the Tuaregs communities. Across the continent, cattle remain major socio-cultural assets and they play important socialcultural roles in many African societies (e.g. marriage, initiation). Besides these major socio-cultural roles, African cattle represent a major source of animal protein (dairy product and beef), provide draft power, thus support crop farming, and fertilizer through manure, which is also used as fuel by some communities.

Although African indigenous breeds generally perform poorly compared to commercial cattle breeds, the latter having been continuously selected for specific productivity traits (e.g. Angus cattle for beef production, HolsteinFriesian cattle for milk), some indigenous African breeds are known to have both good dairy and beef characteristics (Collier and Gunning, 1999; Ndumu et al., 2008; Kugonza 
Table 1. Examples of indigenous cattle breeds with unusual characteristics in sub-Saharan Africa (DAGRIS 2007)

\begin{tabular}{|c|c|c|}
\hline Group & Breed name & Characteristics \\
\hline \multirow[t]{2}{*}{ Humpless Longhorns } & Kuri & Excellent swimmers, intolerant to heat and sunlight \\
\hline & N'Dama & Tolerance to trypanosomosis and cattle ticks \\
\hline \multirow[t]{2}{*}{ Humpless Shorthorns } & Savanna Muturu & Sexual dimorphism on body size, well-fleshed body \\
\hline & Sheko & Tolerance to trypanosomosis \\
\hline \multirow[t]{5}{*}{ Large East African Zebu } & Barka & Active disposition \\
\hline & Karamajong zebu & Adapted to a very dry climate \\
\hline & Kenyan Boran & $\begin{array}{l}\text { Walking ability, highly adapted to harsh conditions, herd instinct, mothering } \\
\text { ability, longevity, large sex dimorphism }\end{array}$ \\
\hline & Orma Boran & Tolerance to trypanosomosis \\
\hline & Turkana & survive on very poor pasture and scarce water, walking ability \\
\hline \multirow[t]{7}{*}{ Small East African Zebu } & Angoni & Adapted to browsing during dry season, variable coat color and size of horns \\
\hline & Arsi & Poor milkers, extremely active and often very aggressive \\
\hline & Jem-Jem & Well adapted to the wet and cold climate \\
\hline & Mongolla & Expected tolerance to trypanosomosis, well fleshed \\
\hline & Nuba Mountain Zebu & Dwarf, tolerance to trypanosomosis \\
\hline & Ogaden & Good dairy and beef characteristics \\
\hline & Ugogo Grey & Adapted to browsing during dry season \\
\hline \multirow[t]{5}{*}{ West African Zebu } & Azaouak & Very well adapted to drought \\
\hline & Red Fulani & Nervous and intractable temperament, poor milkers \\
\hline & Sudanese Fulani & Good walking ability \\
\hline & White Fulani & Good dairy and beef characteristics \\
\hline & Yola & Expected tolerance to trypanosomosis, highly variable conformation \\
\hline \multirow[t]{2}{*}{ East African Sanga } & Bahima* & Susceptible to rinderpest and trypanosomosis \\
\hline & Raya-Azebo & Good draught power \\
\hline \multirow[t]{7}{*}{ South African Sanga } & Afrikaner & Walking and grazing ability, good mothering ability, longevity \\
\hline & Barotse & Docile temperament making it a good work animal \\
\hline & Landim* & $\begin{array}{l}\text { Well adapted to hot, humid weather as well as dry periods, very resistant to Foot } \\
\text { and Mouth Disease }\end{array}$ \\
\hline & Mashona & High fertility, strong maternal instinct, docile disposition \\
\hline & Nguni & $\begin{array}{l}\text { High fertility, early sexual maturity, good foraging and walking ability, good } \\
\text { mothering ability }\end{array}$ \\
\hline & Tswana & Tolerance to ticks, resistance to the endemic heartwater \\
\hline & Tuli & High fertility, good mothering ability, low calf mortality \\
\hline \multirow[t]{5}{*}{ Zenga } & Alur & Thought to have trypanotolerance \\
\hline & Arado & Docile, good work animal, low milk yield \\
\hline & Bovines of Tete & Thought to have trypanotolerance \\
\hline & Fogera & Docile temperament \\
\hline & Horro & Calm disposition, variable milk production \\
\hline Recently derived breeds & Borgou & Sexual dimorphism \\
\hline
\end{tabular}

* Endangered cattle breeds.

et al., 2011). For example, the White Fulani cattle (West African Zebu), which inhabit Cameroon in the Central African Republic and Nigeria, show good performance both as a dairy and beef breed (Pullan and Grindle, 1980). Other well-known beef-dairy cattle are Ogaden cattle (Small East African Zebu) (Rege and Tawah, 1999), Jiddu cattle (Zenga) (Box, 1968), and Fogera cattle (Zenga) (Gebremedhin et al., 2007). While the Kenana and Butana cattle from Sudan are amongst the best milk producing zebu breeds (Musa et al., 2005).

For commercial cattle breeds artificial selection and management interventions have resulted in markedly productivity improvements and by extension, economic performance but at the cost of reduced genetic diversity and in some case fertility (Pryce et al., 2004; De Roos et al., 2008). In contrast, most African cattle breeds have not been selected consistently for productivity gains. Rather the main selection focus has been on survival, in often unpredictable, harsh and changing environmental conditions. Although some element of artificial selection pressures have been applied as illustrated by the high cultural value of some African breeds (e.g. Ankole) (Ndumu et al., 2008; Kugonza 
et al., 2011).

From an examination of microsatellite DNA variation, African cattle breeds are reported to have higher genetic diversity than cattle breeds in other regions (MacHugh et al., 1997; Loftus et al., 1999; Ndumu et al., 2008). Linkage disequilibrium (LD), the nonrandom association of alleles at two or more loci (Falconer, 1981), values for African cattle breeds (e.g. N'Dama, East African Shorthorn Zebu) tends also to be lower compared to other cattle breeds (Goddard and Hayes, 2009; Mbole-Kariuki et al., 2014). Lower LD values in African cattle breeds could indicate that African cattle have often larger gene pools as genetic resources than other cattle breeds, such as Holstein or Angus breeds.

\section{GENOMICS STUDIES OF AFRICAN CATTLE}

Until now African indigenous cattle are relatively less intensively studied at the genome level. However, the situation is expected to change rapidly with several ongoing studies. All published African genome wide analyses have used so far the Illumina $50 \mathrm{~K}$ bead single nucleotide polymorphisms (SNPs) chips. Decker et al. (2014) studied on worldwide patterns of ancestry, divergence, and admixture in domesticated cattle and African Bos taurus cattle populations. As mentioned above they identified unique African cattle autosomal background, which may have originated from local auroch introgression. Although, alternative explanation are possible (e.g. genetic drift and/or ascertainment bias of the SNPs chip).Makina et al. (2014) have reported the genome wide genetic diversity of four indigenous South African breeds, while the detailed genetic architecture and population structure of an East African Shorthorn Zebu cattle population has been reported (MboleKariuki et al., 2014), with Murray et al. (2013) showing evidence of inbreeding as well as outbreeding depression in the same population. West African cattle have also been studied (Gautier et al., 2010), including the first evidence of adaptive genetic divergence in African cattle through "genome-wide" SNPs analysis (Gautier et al., 2009).

No African cattle genome of reference have yet been published. However, two European taurine cattle genome of reference are today available but no zebu $B$. indicus genome. Also, there are no publically available African taurine genome of reference. Given the mixed breed nature of most African cattle population and the presence of a unique African taurine lineage on the continent, the availability of these reference genomes are important for genomic studies of African cattle.

Genome sequencing of African cattle will allow = the development of African cattle specific genomic tools (e.g. African cattle high density SNPS chips), which could be used in genome wide selection breeding approaches (genome selection). Such chips could also be used for the identification of unique African cattle genomic regions and ultimately the causative mutation of major African cattle adaptive traits.

As a result, future African cattle population would be expected to have high 'functional' genetic diversity, while being adapted to their local environments. There have been many trials to improve productivities of African cattle through crossbreeding. However, such breeding improvement strategy has faced many challenges including adverse nutritional and climatic conditions (Scholtz and Theunissen, 2010). Moreover, African indigenous cattle are endangered of extinction due to rash crossbreeding with exotic breeds (Rege, 1999). According to Reist-Marti, Simianer (2003), diversity of many of African taurine and zebu already reached marginal diversity of endangerment, and future diversity is expected to be a half of current diversity in 20-50 years (Reist-Marti et al., 2003). Thus, deeper genetic studies on African indigenous cattle would be needed to improve cattle breed against future climate changes and preserve current African indigenous cattle as valuable genetic resources.

Phenotypes are controlled by genes (Crick, 1970), and phenotypic variation among organisms sometimes reveals evolutionary adaptations or artificial selection (Glazier et al., 2002). Cattle phenotypes may be under the genetic control of a single or a few loci with major effect (e.g. coat color ) or multiple loci each explaining a small proportion of the observed phenotypic variances (e.g. productivity traits such as milk yield and growth rates) (Ashwell et al., 2004; (Goddard and Hayes, 2009). The later are referred as quantitative trait loci or QTLs. Many QTLs have been mapped in cattle ((Hu et al.,2013), including disease tolerance in indigenous African cattle (Hanotte et al., 2003), and QTL association analysis is used in modern breeding technology for genetic improvement (Kim et al., 2003; Khatkar, 2004).

Tracing the genes and loci of monogenic traits in African cattle would be relatively simple (e.g. Glazier et al., 2002). However research on complex traits in African cattle, given their relatively high genetic diversity would be more challenging than in inbred cattle that have low genetic diversity. In the case of dog species, approximately 30,000 SNPs are needed for between-breed analyses (Sutter et al., 2004) because dogs are highly inbred animals, and this might be similar for most commercial livestock (Zajc et al., 1997). In contrast, hundred thousands of SNPs would be needed for complex traits in Bos taurus and Bos indicus subspecies (Goddard and Hayes, 2009). Moreover, information from association studies with SNPs have clear limitations for explaining complex traits (Lander and Kruglyak, 1995; Andersson and Georges, 2004; Manolio et al., 2009) even though several phenotypes are determined 
by only a few genes (Kim et al., 2003; Andersson and Georges, 2004; Schenkel et al., 2006).

The advent of next-generation-sequencing (NGS) technology (Shendure and $\mathrm{Ji}, 2008$ ), has made the production of genetic information much easier (Mardis, 2008) and it is now possible to use not only partial genome information but entire genomes ones from individuals (Davey et al., 2011).

As already been mentioned, most African cattle have a Bos indicus ancestry, and the common ancestor of Bos taurus and Bos indicus dates back to over 330,000 or even 2 million years ago (Ajmone-Marsan et al., 2010). This could represent a challenge for genomic analyses that use the today European taurine cattle genomes of reference. Fortunately, a previous study using NGS whole genome sequence information showed 92 percent to 99 percent overall alignment rates between Bos indicus and the reference genome for taurine, except for the $Y$ chromosome likely because of its incomplete sequence assembly (Canavez et al., 2012). Thus, major difficulties are not expected when performing resequencing analyses using NGS methods.

Nevertheless, re-sequencing analyses using reference genome of European Bos taurus have clear limitations such as missing information of unaligned genome regions or inaccurate reflection of structure variations. As an extreme case, single nucleotide substitutions occur at a mean rate of about $1.2 \%$ between human and chimpanzee genome (Mikkelsen et al., 2005), but the structure of the genome between human and chimpanzee differ considerably because of structural variants including genomic insertion, deletion and even inversions (Newman et al., 2005). These limitations could make exact identification of African cattle genome diversity difficult. A complementary method, denovo genome assembly would therefore help overcome limitations in genomic research of African indigenous cattle.

\section{CONCLUSION}

Agro-ecological zones, directly influenced by climate variation are perhaps more diverse on the African continent than on any other continents. Consequently African indigenous cattle inhabiting these areas are expected to show a mosaic of environmental adaptation key to their survival in local production systems. Identification of these adaptations is not anymore beyond reach thanks to the availability of new genomic tools as well as smarter phenotyping tools and procedures.

The genetic diversity of African indigenous represent an unique resource and opportunity for tackling the challenges of livestock productivity faced by the African continent, including the increase demand for livestock products and the consequence of climate instability and changes. It is up to us to understand it and to exploit it now for the benefit of the African continent and its population.

\section{ACKNOWLEDGMENTS}

This work was supported by a grant from the NextGeneration BioGreen 21 Program (Project No. PJ01134905), Rural Development Administration, Republic of Korea. We thank Steve Kemp, Tadelle Dessie, Hak-Kyo Lee, SungJong Oh, and Heebal Kim for constructive suggestions on the study and for helpful comments on the manuscript.

\section{REFERENCES}

Ajmone-Marsan, P., J. F. Garcia, and J. A. Lenstra. 2010. On the origin of cattle: How aurochs became cattle and colonized the world. Evol. Anthropol. Issues, News, Reviews 19:148-157.

Andersson, L. and M. Georges. 2004. Domestic-animal genomics: Deciphering the genetics of complex traits. Nat. Rev. Genet. 5:202-212.

Ashwell, M., D. Heyen, T. Sonstegard, C. Van Tassell, Y. Da, P. VanRaden, M. Ron, J. Weller, and H. Lewin. 2004. Detection of quantitative trait loci affecting milk production, health, and reproductive traits in Holstein cattle. J. Dairy Sci. 87:468-475.

Asselbergs, M., F. Jongejan, A. Langa, L. Neves, and S. Afonso. 1993. Antibodies toCowdria ruminantium in Mozambican goats and cattle detected by immunofluorescence using endothelial cell culture antigen. Trop. Anim. Health Prod. 25:144-150.

Blench, R. M. and K. C. MacDonald. 2006. The origins and development of African livestock: archaeology, genetics, linguistics and ethnography. Routledge, London, UK.

Bonfiglio, S., C. Ginja, A. De Gaetano, A. Achilli, A. Olivieri, L. Colli, K. Tesfaye, S. H. Agha, L. T. Gama, F. Cattanaro, M. C. T. Penedo, P. Ajmone-Marsan, A. Torroni, and L. Ferretti. 2012. Origin and spread of Bos taurus: New clues from mitochondrial genomes belonging to haplogroup T1. PLoS ONE 7(6):e38601.

Bradley, D. G., D. E. MacHugh, R. T. Loftus, R. S. Sow, C. H. Hoste, and E. P. Cunningham. 1994. Zebu-taurine variation in Y chromosomal DNA: a sensitive assay for genetic introgression in West African trypanotolerant cattle populations. Anim. Genet. 25:7-12.

Buffum, B. C. 1909. Arid Agriculture: A Hand-book for the Western Farmer and Stockman. Self published, Worland, WY, USA.

Canavez, F. C., D. D. Luche, P. Stothard, K. R. M. Leite, J. M. Sousa-Canavez, G. Plastow, J. Meidanis, M. A. Souza, P. Feijao, S. S. Moore, and L. H. Camara-Lopes. 2012. Genome sequence and assembly of Bos indicus. J. Hered. doi: 10.1093/jhered/esr153.

Chimpanzee Sequencing and Analysis Consortium. 2005. Initial sequence of the chimpanzee genome and comparison with the human genome. Nature 437:69-87.

Collier, P. and J. W. Gunning. 1999. Explaining African economic performance. J. Econ. Lit. 37:64-111.

Crick, F. 1970. Central dogma of molecular biology. Nature 
227:561-563.

DAGRIS. 2007. Domestic Animal Genetic Resources Information System (DAGRIS). (eds S. Kemp, Y. Mamo, B. Asrat and T. Dessie). International Livestock Research Institute, Addis Ababa, Ethiopia.

Davey, J. W., P. A. Hohenlohe, P. D. Etter, J. Q. Boone, J. M. Catchen, and M. L. Blaxter. 2011. Genome-wide genetic marker discovery and genotyping using next-generation sequencing. Nat. Rev. Genet. 12:499-510.

De Roos, A. P. W., B. J. Hayes, R. J. Spelman, and M. E. Goddard. 2008. Linkage disequilibrium and persistence of phase in Holstein-Friesian, Jersey and Angus cattle. Genetics 179:1503-1512.

Decker, J. E., S. D. McKay, M. M. Rolf, J. Kim, A. M. Alcalá, T. S. Sonstegard, O. Hanotte, A. Götherström, C. M. Seabury, and L. Praharani et al. 2014. Worldwide patterns of ancestry, divergence, and admixture in domesticated cattle. PLoS Genet 10(3):e1004254.

Edwards, C. J., R. Bollongino, A. Scheu, A. Chamberlain, A. Tresset, J.-D. Vigne, J. F. Baird, G. Larson, S. Y. Ho, and T. H. Heupink et al. 2007. Mitochondrial DNA analysis shows a Near Eastern Neolithic origin for domestic cattle and no indication of domestication of European aurochs. Proceedings of the Royal Society of London B: Biological Sciences 274:1377-1385.

Epstein, H. and I. L. Mason. 1971. Origin of the Domestic Animals of Africa. Holmes \& Meier, NY, USA.

Falconer, D. S. 1960. Introduction to Quantitative Genetics DS Falconer. Longman, London, England.

Felius, M. 1995. Cattle Breeds: An Encyclopedia. Misset, Doetinchem, Netherlands.

Flint, A. P. F. and J. A. Woolliams. 2008. Precision animal breeding. Philosophical Transactions of the Royal Society B: Biological Sciences 363:573-590.

Freeman, A., D. G. Bradley, S. Nagda, J. P. Gibson, and O. Hanotte. 2006. Combination of multiple microsatellite data sets to investigate genetic diversity and admixture of domestic cattle. Anim. Genet. 37:1-9.

Gautier, M., L. Flori, A. Riebler, F. Jaffrézic, ,D. Laloë, I. Gut, and K. Moazami-Goudarzi and J.-L. Foulley. 2009. A whole gneome Bayesian scan for adaptive genetic divergence in West African cattle. BMC Genomics. 10:550. doi:10.1186/14712164-10-550.

Gautier, M., D. Laloë, and K. Moazami-Goudarzi. 2010. Insights into the genetic history of French cattle from dense SNP data on 47 worldwide breeds. PLoS One 5(9):e13038.

Gebremedhin, B., D. Hoekstra, and S. Jemaneh. 2007. Heading towards commercialization? The case of live animal marketing in Ethiopia. International Livestock Research Institute, Nairobi, Kenya.

Glazier, A. M., J. H. Nadeau, and T. J. Aitman. 2002. Finding genes that underlie complex traits. Science 298:2345-2349.

Goddard, M. E. and B. J. Hayes. 2009. Mapping genes for complex traits in domestic animals and their use in breeding programmes. Nat. Rev. Genet. 10:381-391.

Habier, D., R. L. Fernando, and J. C. M. Dekkers. 2007. The impact of genetic relationship information on genome-assisted breeding values. Genetics 177:2389-2397.

Hanotte, O., D. G. Bradley, J. W. Ochieng, Y. Verjee, E. W. Hill, and J. E. O. Rege. 2002. African pastoralism: genetic imprints of origins and migrations. Science 296:336-339.

Hanotte, O., T. Dessie, and S. Kemp. 2010. Time to tap Africa's livestock genomes. Science (Washington) 328:1640-1641.

Hanotte, O., M. Okomo, Y. Verjee, J. Rege, and A. Teale. 1997. A polymorphic $\mathrm{Y}$ chromosome microsatellite locus in cattle. Anim. Genet. 28:318-319.

Hanotte, O., Y. Ronin, M. Agaba, P. Nilsson, A. Gelhaus, R. Horstmann, Y. Sugimoto, S. Kemp, J. Gibson, and A. Korol. 2003. Mapping of quantitative trait loci controlling trypanotolerance in a cross of tolerant West African N'Dama and susceptible East African Boran cattle. Proc. Natl. Acad. Sci. 100:7443-7448.

Hanotte, O., C. L. Tawah, D. G. Bradley, M. Okomo, Y. Verjee, J. Ochieng, and J. Rege. 2000. Geographic distribution and frequency of a taurine Bos taurus and an indicine Bos indicus Y specific allele amongst sub-Saharan African cattle breeds. Mol. Ecol. 9:387-396.

Hansen, P. J. 2004. Physiological and cellular adaptations of zebu cattle to thermal stress. Anim. Reprod. Sci. 82:349-360.

Hayes, B. J., H. A. Lewin, and M. E. Goddard. 2013. The future of livestock breeding: genomic selection for efficiency, reduced emissions intensity, and adaptation. Trends Genet. 29:206-214.

Hiendleder, S., H. Lewalski, and A. Janke. 2008. Complete mitochondrial genomes of Bos taurus and Bos indicus provide new insights into intra-species variation, taxonomy and domestication. Cytogenet. Genome Res. 120:150-156.

Houghton, J. T. and B. A. Callander. 1992. Climate change 1992: the supplementary report to the IPCC scientific assessment. Cambridge University Press, Cambridge, UK.

Hu, Z.-L., C. A. Park, X.-L. Wu, and J. M. Reecy. 2013. Animal QTLdb: an improved database tool for livestock animal QTL/association data dissemination in the post-genome era. Nucl. Acids Res. 41:D871-D879.

ILRI. 2006. Safeguarding livestock diversity: The time is now. Annual Report 2006. International Livestock Research Institute, Nairobi, Kenya.

Khatkar, M. S., P. C. Thomson, I. Tammen, and H. W. Raadsma. 2004. Quantitative trait loci mapping in dairy cattle: review and meta-analysis. Genet. Sel. Evol. 36:163-190.

Kim, J.-J., F. Farnir, J. Savell, and J. F. Taylor. 2003. Detection of quantitative trait loci for growth and beef carcass fatness traits in a cross between Bos taurus (Angus) and Bos indicus (Brahman) cattle. J. Anim. Sci. 81:1933-1942.

Kugonza, D. R., M. Nabasirye, D. Mpairwe, O. Hanotte, and A. Okeyo. 2011. Productivity and morphology of Ankole cattle in three livestock production systems in Uganda. Anim. Genet. Res. 48:13-22.

Lander, E. and L. Kruglyak. 1995. Genetic dissection of complex traits: guidelines for interpreting and reporting linkage results. Nat. Genet. 11:241-247.

Lemecha, H., W. Mulatu, I. Hussein, E. Rege, T. Tekle, S. Abdicho and W. Ayalew. 2006. Response of four indigenous cattle breeds to natural tsetse and trypanosomosis challenge in the Ghibe valley of Ethiopia. Vet. Parasitol. 141:165-176.

Linseele, V. 2004. Size and size change of the African aurochs. J. Afr. Archaeol. 2:165-185.

Loftus, R., O. Ertugrul, A. H. Harba, M. A. A. El-Barody, D. E. MacHugh, S. D. E. Park, and D. G. Bradley. 1999. A 
microsatellite survey of cattle from a centre of origin: the Near East. Mol. Ecol. 8:2015-2022.

Loftus, R. T., D. E. Machugh, D. G. Bradley, P. M. Sharp, and P. Cunningham. 1994. Evidence for two independent domestications of cattle. Proc. Natl. Acad. Sci. 91:2757-2761.

MacHugh, D. E., M. D. Shriver, R. T. Loftus, P. Cunningham, and D. G. Bradley. 1997. Microsatellite DNA variation and the evolution, domestication and phylogeography of taurine and zebu cattle (Bos taurus and Bos indicus). Genetics 146:10711086.

Makina, S. O., F. C. Muchadeyi, E. van Marle-KÖster, M. D. MacNeil, and A. Maiwashe. 2014. Genetic diversity and population structure among six cattle breeds in South Africa using a whole genome SNP panel. Front. Genet. 5:533. Front Genet. 2014; 5: 333.doi: 10.3389/fgene.2014.00333.

Manolio, T. A., F. S. Collins, N. J. Cox, D. B. Goldstein, L. A. Hindorff, D. J. Hunter, M. I. McCarthy, E. M. Ramos, L. R. Cardon, and A. Chakravarti et al. 2009. Finding the missing heritability of complex diseases. Nature 461:747-753.

Mardis, E. R. 2008. The impact of next-generation sequencing technology on genetics. Trends Genet. 24:133-141.

Marshall, F. and E. Hildebrand. 2002. Cattle before crops: the beginnings of food production in Africa. J. World Prehist. 16:99-143.

Mattioli, R. C., V. S. Pandey, M. Murray, and J. L. Fitzpatrick. 2000. Immunogenetic influences on tick resistance in African cattle with particular reference to trypanotolerant N'Dama (Bos taurus) and trypanosusceptible Gobra zebu (Bos indicus) cattle. Acta Trop. 75:263-277.

Mbole-Kariuki, M. N., T. Sonstegard, A. Orth, S. M. Thumbi, B. M. de C. Bronsvoort, H. Kiara, P. Toye, I. Conradie, A. Jennings, K. Coetzer, M. J. J. Woolhouse, O. Hanotte, M. Tapio. 2014. Genome-wide analysis reveals the ancient and recent admixture history of East African Shorthorn Zebu from Western Kenya. Heredity 113:297-305.

Murray, M., W. Morrison, and D. Whitelaw. 1982. Host susceptibility to African trypanosomiasis: Trypanotolerance. Adv. Parasitol. 21:1-68.

Murray, M., J. C. M. Trail, C. E. Davis, and S. J. Black. 1984. Genetic resistance to African trypanosomiasis. J. Infect. Dis. 149:311-319.

Murray, G. G. R., M. E. J. Woolhouse, M. Tapio, M. N. MboleKariuki, T. S. Sonstegard, S. M. Thumbi, A. E. Jennings, I. C. van Wyk, M. Chase-Topping, and H. Kiara et al. 2013. Genetic susceptibility to infectious disease in East African Shorthorn Zebu: A genome-wide analysis of the effect of heterozygosity and exotic introgression. BMC Evol. Biol. 13:246.

Musa, L. M. A., M. A. Ahmed, K. J. Peters, B. Zumbach, and K. E. A. Gubartalla. 2005. The reproductive and milk performance merit of Butana cattle in Sudan. Arch. Tierz. 48:445-459.

Nardone, A., B. Ronchi, N. Lacetera, M. S. Ranieri, and U. Bernabucci. 2010. Effects of climate changes on animal production and sustainability of livestock systems. Livest. Sci. 130:57-69.

Newman, T. L., E. Tuzun, V. A. Morrison, K. E. Hayden, M. Ventura, S. D. McGrath, M. Rocchi, and E. E. Eichler. 2005. A genome-wide survey of structural variation between human and chimpanzee. Genome Res. 15:1344-1356.

Ndumu, D. B., R. Baumung, O. Hanotte, M. Wurzinger, M. A.
Okeyo, H. Jianlin, H. Kibogo, and J. Solkner. 2008. Genetic and morphological characterisation of the Ankole Longhorn cattle in the African Great Lakes region. Genet. Sel. Evol. 40:467-490.

Njogu, A., R. Dolan, A. Wilson, and P. Sayer. 1985. Trypanotolerance in East African Orma Boran cattle. Vet. Rec. 117:632-636

Okello, S. and E. N. Sabiiti. 2006. Milk production of indigenous Ankole cattle in Uganda as influenced by seasonal variations in temperature, rainfall and feed quality. Makerere Univ. Res. J. 1:73-92.

Otten, D. and H. F. Van den Weghe. 2011. The Sustainability of Intensive Livestock Areas (ILAS): Network system and conflict potential from the perspective of animal farmers. Int. J. Food Syst. Dyn. 2:36-51.

Payne, W. 1964. The origin of domestic cattle in Africa. Emp. J. Exp. Agric. 32:97-113.

Piper, E. K., N. N. Jonsson, C. Gondro, A. E. Lew-Tabor, P. Moolhuijzen, M. E. Vance, and L. A. Jackson. 2009. Immunological profiles of Bos taurus and Bos indicus cattle infested with the cattle tick, Rhipicephalus (Boophilus) microplus. Clin. Vaccine Immunol. 16:1074-1086.

Porto-Neto, L. R., T. S. Sonstegard, G. E. Liu, D. M. Bickhart, M. V. Da Silva, M. A. Machado, Y. T. Utsunomiya, J. F. Garcia, C. Gondro, and C. P. Van Tassell. 2013. Genomic divergence of zebu and taurine cattle identified through high-density SNP genotyping. BMC Genomics 14:876.

Pryce, J. E., M. D. Royal, P. C. Garnsworthy, and I. L. Mao. 2004. Fertility in the high-producing dairy cow. Livest. Prod. Sci. 86:125-135.

Pullan, N. B. and R. J. Grindle. 1980. Productivity of white Fulani cattle on the Jos plateau, Nigeria. IV. Economic factors. Trop. Anim. Health Prod. 12:161-170.

Rege, J. E. O. 1999. The state of African cattle genetic resources I. Classification framework and identification of threatened and extinct breeds. Anim. Genet. Res. Inf. 25:1-25.

Rege, J. E. O. and C. L. Tawah. 1999. The state of African cattle genetic resources II. Geographical distribution, characteristics and uses of present-day breeds and strains. Anim. Genet. Res. Inf. 26:1-25.

Reist-Marti, S. B., H. Simianer, J. Gibson, O. Hanotte, and J. E. O. Rege. 2003. Weitzman's approach and conservation of breed diversity: An application to African cattle breeds. Conserv. Biol. 17:1299-1311.

Renaudeau, D., A. Collin, S. Yahav, V. De Basilio, J. L. Gourdine, and R. J. Collier. 2012. Adaptation to hot climate and strategies to alleviate heat stress in livestock production. Animal 6:707728.

Roberts, C. J. and A. R. Gray. 1973. Studies on trypanosomeresistant cattle. II. The effect of trypanosomiasis on N'Dama, Muturu and Zebu cattle. Trop. Anim. Health Prod. 5:220-233.

Ruttledge, W. 1928. Tsetse-fly (Glossina morsitans) in the Koalib Hills, Nuba Mountains Province, Sudan. Bull. Entomol. Res. 19:309-316.

Schenkel, F. S., S. P. Miller, Z. Jiang, I. B. Mandell, X. Ye, H. Li, and J. W. Wilton. 2006. Association of a single nucleotide polymorphism in the calpastatin gene with carcass and meat quality traits of beef cattle. J. Anim. Sci. 84:291-299.

Scholtz, M. M. and A. Theunissen. 2010. The use of indigenous cattle in terminal cross-breeding to improve beef cattle 
production in Sub-Saharan Africa. Anim. Genet. Res. 46:33-39. Thomas, A. S. 1943. The vegetation of the Karamoja district, Shendure, J. and H. Ji. 2008. Next-generation DNA sequencing. Nat. Biotechnol. 26:1135-1145.

Uganda: An illustration of biological factors in tropical ecology. J. Ecol. 31:149-177.

Stock, F. and D. Gifford-Gonzalez. 2013. Genetics and African cattle domestication. Afr. Archaeol. Rev. 30:51-72.

Sutter, N. B., M. A. Eberle, H. G. Parker, B. J. Pullar, E. F. Kirkness, L. Kruglyak, and E. A. Ostrander. 2004. Extensive and breed-specific linkage disequilibrium in Canis familiaris. Genome Res. 14:2388-2396.

Terefe, E., A. Haile, W. Mulatu, T. Dessie, and O. Mwai. 2015. Phenotypic characteristics and trypanosome prevalence of Mursi cattle breed in the Bodi and Mursi districts of South Omo Zone, southwest Ethiopia. Trop. Anim. Health Prod. 47:485-493.

Troy, C. S., D. E. MacHugh, J. F. Bailey, D. A. Magee, R. T. Loftus, P. Cunningham, A. T. Chamberlain, B. C. Sykes, and D. G. Bradley. 2001. Genetic evidence for Near-Eastern origins of European cattle. Nature 410:1088-1091.

Wendorf, F. and R. Schild. 1994. Are the early Holocene cattle in the Eastern Sahara domestic or wild? Evol. Anthropol. Issues, News, Reviews 3:118-128.

Zajc, I., C. S. Mellersh, and J. Sampson. 1997. Variability of canine microsatellites within and between different dog breeds. Mamm. Genome 8:182-185. 